\title{
HOLOPROSENCEPHALY: CHROMOSOMAL ABNORMALITIES IN THE ETIOPATHOGENESIS OF 127 ANTENATAL CASES
}

\author{
HOLOPROZENSEFALI: 127 ANTENATAL OLGUNUN ETYOPATOGENEZINDE \\ KROMOZOM ANOMALILERI
}

\author{
Birsen KARAMAN ${ }^{1,2}$ (D), Selvi ERGiN² (D), Hülya KAYSERILi2,4 (D), Atıl YÜKSEL ${ }^{3}$ (D) Nihan Bilge SATKIN² (D),

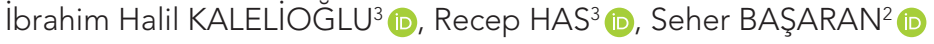 \\ ${ }^{1}$ Istanbul University, Child Health Instute, Pediatric Basic Sciences, Istanbul, Turkey \\ ${ }^{2}$ Istanbul University, Istanbul Faculty of Medicine, Department of Medical Genetics, Istanbul, Turkey \\ ${ }^{3}$ Istanbul University, Istanbul Faculty of Medicine, Department of Obstetrics and Gynecology, Division of Perinatology, Istanbul, Turkey \\ ${ }^{4}$ Koç University, School of Medicine, Medical Genetics Department, Istanbul, Turkey
}

ORCID IDs of the authors: B.K. 0000-0001-8640-0176; H.K. 0000-0003-0376-499X; A.Y. 0000-0002-6487-0860; S.E. 0000-0002-5817-624X; B.N.S. 0000-0003-2257-4294; i.H.K. 0000-0003-1349-2561; R.H. 0000-0002-1372-8506; S.B. 0000-0001-8668-4746

Cite this article as: Karaman B, Ergin S, Kayserili H, Yuksel A, Satkin NB, Kalelioglu IH, et al. Holoprosencephaly: chromosomal abnormalities in the etiopathogenesis of 127 antenatal cases. J Ist Faculty Med 2021;84(2):186-91. doi: 10.26650/IUITFD.2020.0071

\section{ABSTRACT}

Objective: Holoprosencephaly (HPE, \#MIM 236100) is the most common developmental defect of midline cleavage in the human forebrain. Environmental, genetic, and multifactorial causes are involved in its etiology. About half of the cases have chromosome aberrations such as trisomies 13 and 18, triploidy and structural imbalances. Single gene mutations have been shown in $\sim 25 \%$ of cases. In this retrospective study, we aimed to determine the etiological factors related to HPE in 127 fetuses.

Material and Method: This study comprises 127 prenatally diagnosed fetal HPE samples from a period of 25 years, which were evaluated by karyotyping, fluorescence in situ hybridization (FISH) and aCGH investigation.

Results: A total of 64 (50.39\%) chromosome aberrations were identified in this cohort. The predominant chromosomal abnormality was trisomy $13(n=38)$, which was followed by trisomy $18(n=8)$ and triploidy $(n=5)$. Terminal $7 q$ deletion was the most frequent structural anomaly ( $n=10$, of which 5 were de novo deletion, 4 were an unbalanced product of maternal translocations and one unknown in origin) and the deletion of 18p was detected in one case. In the remaining two cases, we detected trisomy 20 and pericentric inversion 11 coincidentally.

Conclusion: This study, indicates that in the presence of clinical findings suggesting HPE, cytogenetic and molecular cytogenetic studies should be performed. An aCGH study must also be done for submicroscopic chromosomal anomalies, to determine

\begin{abstract}
ÖZET
Amaç: Holoprosensefali (HPE, \#MIM 236100), ön beyin orta hat bölünmesinde en sık görülen gelişimsel bozukluktur. Etiyolojisinde, çevresel, genetik ve multifaktöriyel hastalıklar rol oynamaktadır. Vakaların yaklaşık yarısında, trizomi 13 başta olmak üzere, trizomi 18 ve triploidi gibi sayısal anomaliler ve yapısal kromozom anomalileri bulunmaktadır. Olguların \%25'inde tek gen mutasyonları gösterilmiştir. Bu retrospektif çalışmada fetal dönemde saptanan 127 fetüste HPE etiyolojisinde rol oynayan faktörlerin araştırılması planlandı.
\end{abstract}

Gereç ve Yöntem: Bu çalışma, 25 yıllık bir periyotta fetal ultrasonografide HPE tanısı konmuş 127 fetusta yapılan klasik karyotipleme, floresan in situ hibridizasyon (FISH) ve aCGH incelemelerinin sonuçlarını içermektedir.

Bulgular: Bu kohortta olguların 64 (\%50,39)'ünde bir kromozom anomalisi tespit edildi. En sık görülen sayısal kromozomal anomali beklendiği gibi trizomi 13 ( $n=38)$ idi , bunu sırasıyla trizomi $18(n=8)$ ve triploidi $(n=5)$ izlemiştir. Yapısal kromozom anomalilerinden terminal $7 q$ delesyonu en sık görülen anomaliydi $(n=10$, 5'i de novo, 4'ü maternal translokasyonun dengesiz ürünü, 1 olgunun kökeni ise bilinmiyordu). Bir olguda 18. kromozomun $p$ kolunda bir delesyon saptandı. Kalan 2 olguda tesadüfi olarak trizomi 20 ve 11. kromozomda perisenttrik bir inversiyon saptandı.

Sonuç: Bu çalışma, HPE klinik bulguların varlığında sitogenetik ve moleküler sitogenetik çalışmaların birlikte veya tamamlayıcı olarak yapılması gerektiğini göstermektedir. Özellikle aCGH ça-

Corresponding author/iletişim kurulacak yazar: bkaraman@istanbul.edu.tr

Submitted/Başvuru: 09.06.2020 • Revision Requested/Revizyon Talebi: 15.07.2020 •

Last Revision Received/Son Revizyon: 08.09.2020 • Accepted/Kabul: 19.10.2020 • Published Online/Online Yayın: 31.03 .2021 
their sizes, real breakpoints and identify possible novel genes that might play a role in HPE etiology.

Keywords: Holoprosencephaly, HPE, \#MIM 236100, nervous system malformations, prenatal diagnosis

\section{INTRODUCTION}

Holoprosencephaly (HPE, \#MIM 236100), resulting from failed forebrain separation during early embryogenesis, is the most common developmental defect in humans with an incidence of 1:250 in first trimester fetuses and 1:10 000 in newborns (1).

This malformation of the forebrain is often associated with a wide spectrum of facial anomalies, from severe to mild, such as cyclopia with proboscis, hypoplasia of the nose with a single nostril, agenesis of the premaxilla, cleft lip/palate, midfacial hypoplasia, single maxillary central incisor and hypotelorism. According to central nervous system (CNS) findings, HPE is classified into 4 groups: (i) alobar, when the hemispheres are not separated and a "monoventricle" is formed; (ii) semilobar, when the hemispheres and ventricles are partly separated and the interhemispheric fissure is only posteriorly present; (iii) lobar, when the cerebral hemispheres and lateral ventricles are separated but variable regions may partly or mildly be fused, and the peripheral olfactory nerves and bulbs are absent, and (iv) the middle interhemispheric fusion variant (MIHV), when the posterior-frontal and parietal lobes are not separated and the corpus callosum is absent (2-5).

HPE is an etiologically heterogeneous condition, which can result from chromosome aberrations, single gene mutations or environmental factors. Chromosomal aberrations are the most common etiological factor, detected in about $50 \%$ of affected individuals. Numerical (trisomy 13 , trisomy 18 and triploidy), as well as structural chromosomal anomalies including submicroscopic aberrations have been associated with HPE. Structural chromosomal anomalies led the way in identifying the genes and pathways related to HPE. After the identification of Sonic Hedgehog $(\mathrm{SHH})$ at $7 \mathrm{q} 36$ in 1996,14 genes and 35 related loci have been published (6-8). ZIC2 at 13q32, SIX3 at 2p21, TGIF1 at 18p11.3, PTCH1 at 9q22 are reported as major causative genes and mutations in those genes are identified in about $25 \%$ of chromosomally normal cases (9-12). Single gene mutations are mostly identified in postnatal than in prenatal cases since major chromosome aberrations are lethal $(13,14)$.

We report here the results of classical and molecular karyotyping in 127 fetuses with HPE detected antenatally by ultrasonographic or fetal MRI evaluation. lışması submikroskopik yapısal kromozomal anomalilerin boyutlarını ve kırık noktalarını, bölgede yer alan genleri belirlemekte olduğu kadar HPE etiyolojisinde rol oynayabilecek olası yeni genleri tanımlamak için de yapılmalıdır.

Anahtar Kelimeler: Holoprosensefali, HPE, \#MIM 236100, merkezi sinir sistemi, prenatal tanı

\section{MATERIAL AND METHOD}

This study consists of classical karyotyping, and molecular cytogenetic examination of 127 samples from fetal tissue following the prenatal diagnosis (PD) of HPE. The examinations were carried out at the Medical Genetics Department of Istanbul Faculty of Medicine, Istanbul University, during a time span of 25-years. Fetal ultrasonography (USG) and invasive procedures were performed at the Perinatology Division of the Obstetrics and Gynecology Department of the same faculty. Fetal tissue samples were obtained by chorionic villus sampling ( $n=34)$, amniocentesis $(n=26)$ and fetal blood sampling $(n=67)$. Karyotype analysis was performed using G-banded chromosomes at 500-550 band levels (except for 4 cases, examined at 400-450 band-levels). After 2007, cases with normal karyotype or a deletion encompassing the $7 q 36$ band were further investigated with FISH using subtelomeric probe 7q36.3 ( $n=36)$ (Cytocell, Cambridge, UK). After 2011, aCGH was performed in 29 cases using Agilent SurePrintG3 CGH+SNP Microarray Kit (4x180K), according to the manufacturer protocol. These works were a part of routine clinical genetic evaluation. Written informed consent was obtained from the parents for all genetic tests. This study was approved by the Istanbul University, Istanbul Faculty of Medicine research ethics committee (2011/1275-642, 27.07.2011).

\section{RESULTS}

This study consists of 127 fetal samples with antenatal suspicion of HPE from a single center over a period of 25 years and is the largest series for prenatal work-up of HPE with cytogenetic and molecular cytogenetic analysis. The mean maternal age at the diagnosis was 30.5 years (range 16 to 45 ). The male to female sex ratio of fetuses was 1.2:1. Postmortem physical examinations were performed in 55, and fetal autopsy in 18 fetuses, for confirmation of HPE. The mean gestational age at the time of USG diagnosis was 21.7 weeks (range 11-38).

Fifty-four of the fetuses (42.51\%) presented with alobar, 12 (9.44\%) with semilobar, four with lobar HPE (3.14\%), one with MIHV $(0.787 \%)$ and in 56 (44.09\%) the HPE sub-classification was not performed (Table 1). Two fetuses with a normal result were monozygotic twins. One of the twin pair presented with HPE, although its partner did not display any USG findings of HPE, a minor form could not be excluded. Five families with a history of more than one affected fetus with HPE had normal cytogenetic results. 
Table 1: Distribution of HPE types among chromosomal abnormalities

\begin{tabular}{lccc}
\hline & $\mathrm{n}=\mathbf{1 2 7}$ & $\begin{array}{c}\text { \% ratio in } \\
\text { all cases }\end{array}$ & $\begin{array}{c}\text { \% ratio in } \\
\text { anomalies }\end{array}$ \\
\hline $\begin{array}{l}\text { Normal } \\
\text { karyotype }\end{array}$ & 63 & 49.6 & \\
$\begin{array}{l}\text { Chromosome } \\
\text { abnormalities }\end{array}$ & 64 & 50.4 & \\
$\begin{array}{l}\text { Trisomy 13 } \\
\text { Trisomy 18 }\end{array}$ & 38 & 29.9 & 59.4 \\
$\begin{array}{l}\text { Triploidy } \\
\begin{array}{l}\text { Derivative } \\
\text { chromosomes }\end{array}\end{array}$ & 5 (4 mat+1 & 3.93 & 7.8 \\
7q deletion & 5 (dn) & 3.93 & 7.8 \\
$\begin{array}{l}\text { 18p deletion } \\
\text { Trisomy 20 }\end{array}$ & 1 & 0.78 & 1.56 \\
$\begin{array}{l}\text { Pericentric } \\
\text { inversion }\end{array}$ & 1 & 0.78 & 1.56 \\
\hline
\end{tabular}

Chromosomal aberrations were found in 64 of 127 fetuses (50.39\%) of which 62 (48.81) were considered to be causatively related to the brain malformation. The results are summarized in Figure 1. Of the 57 fetuses investigated by classical karyotyping between 1994 and 2007, 25 (43.85\%) had visible chromosome anomalies (trisomy 13 in 17 cases, triploidy in two, trisomy 18 in one, a derivative chromosome 7 as an unbalanced product of a maternal translocation in three, de novo $7 q$ terminal deletion in one). After 2007, 70 fetal samples were karyotyped, and chromosome anomalies were detected in 39 ( $55.71 \%$ ). The detailed description of the anomalies were as follows; trisomy 13 in 21 , trisomy 18 in seven, triploidy in three, a de novo terminal deletion of $7 \mathrm{q}$ in four (two being the MZ twin pair), a derivative chromosome 7 as an unbalanced product of a maternal translocation in one and deletion 18p detected in one case In addition to those chromosome aberrations which

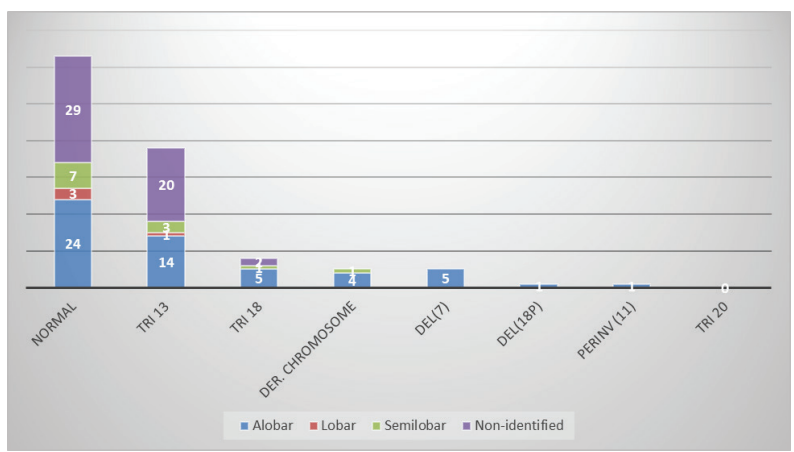

Figure 1: Fetal USG classification of HPE and their relation to karyotype abnormality

DER: Derivative, Tri: Trisomy, DEL: Deletion, PERINV: Pericentric inversion all involve at least one HPE gene, two further presumably unrelated anomalies were detected: one was a pericentric inversion of chromosome 11 inherited from healthy a father, and the other non-mosaic trisomy 20.

Five cases in 4 pregnancies (counted as 2 because one case was twin) maternal unbalanced translocations were identified after fetal karyotyping. All were related to the $7 q 36$ band, and the reciprocal breakpoints were 3p23, $3 q 28,15 q 26.2$ and $21 q 23.3$. All cases with normal karyotype $(n=34)$ were further investigated with FISH using a subtelomeric $7 q$ probe, and four were found to have a $7 \mathrm{q}$ microdeletion. One case had a $3.5 \mathrm{Mb}$ deletion of $18 p$ encompassing the TGIF1 gene with a MLPA P070 probe set. In 29 fetal samples with normal karyotype, aCGH study was performed, and four fetuses with $7 \mathrm{q}$ microdeletion were identified. We detected $7 q$ deletion and $9 p$ duplication in aCGH examination in one case ( 11,5 Mb with coordinates 147,250,584-158,816,094 and 22,3 Mb with coordinates 0-22,266,593), karyotype and FISH analysis of this case were normal. Retrospectively, those two aberrations were missed by karyotyping due to the poor quality of the chromosome preparations (at 400450 band level). All remaining 26 cases with normal karyotypes also had normal aCGH results. ACGH results revealed that the de novo $7 \mathrm{q}$ microdeletions had identical coordinates $(158,816,094)$ at q terminal breakpoints, but proximal breakpoints varied and deletion sizes differed for each case except the monozygotic twins $(147,250,584$; $150,997,359 ; 152,468,942 ;$ and 153,380,709).

\section{DISCUSSION}

HPE arises from developmental failure at the rostral end of the neural tube during early embryogenesis (15). The phenotypic spectrum shows inter and intrafamilial variability, from severe CNS and facial anomalies to clinically normal phenotypes $(16,17)$. It is estimated that only $70 \%$ of obligate carriers show minor clinical features of HPE, suggesting incomplete penetrance and variable expression (16). Thus, chromosomal abnormalities, including numerical, structural, and submicroscopic imbalances were the cause of half of all HPE cases in the present report. All instances, involved known HPE genes.

Gene mutations can also cause both syndromic and non-syndromic HPE. It has been suggested that $25 \%$ of HPE cases carry a mutation in a single gene (18). Teratogenic and environmental agents have also been reported as aetiological factors. Determining the etiology of HPE is important for genetic counselling, especially in estimating the recurrence risk. When numerical aberrations are detected, the recurrence risk is low; although, taking germ line mosaicism into account, foetal karyotyping should be recommended for future pregnancies (19). In cases with structural chromosomal abnormalities, parental studies must be performed to exclude balanced rear- 
rangement with high recurrence risk. The same is true if a submicroscopic alteration is detected by molecular cytogenetic techniques. Another reason for parental studies is phenotypic variability. If a gene mutation or a7q36 microdeletion is detected by mutation analysis, karyotyping and/or FISH, parental studies should be performed to exclude an undetected minor manifestation or even incomplete penetrance, and the parents should also be examined clinically. The MZ twin pair with discordant phenotype displaying de novo 7 q36 microdeletion is a very impressive example of the variable phenotypes caused by the same mutation in SHH (possibly due to epigenetic mechanisms) (20).

The proportion of chromosome anomalies in live births with HPE ranges from $25-45 \%$, and it is distinctly higher in early pregnancy, since numerical abnormalities frequently result in a non-viable foetus. The rate of chromosomal abnormalities in our cohort was $50.4 \%$, and we further confirmed that observation. The mean gestational age at the time of USG diagnosis was 20.1 weeks for cases with numerical chromosome anomalies, and this did not differ significantly from foetuses with structural imbalances and chromosomally normal foetuses (22.5 and 22 weeks, respectively). The detection rate of chromosomal imbalances was $43.9 \%$ in the first period of the study, when only classical karyotyping was available. After the implementation of molecular cytogenetic techniques in 2007, a total of 36 chromosomal imbalances were diagnosed in 70 foetuses with HPE (51.42\%). Theoretically, if the karyotype resolution had been high (>550 band level) in all cases (which is unfortunately not the case in a diagnostic laboratory), with the exception of the $18 p$ microdeletion and three other cases all cytogenetic aberrations in the cohort could have been identified.

According to previously published data, trisomy 13 , including cryptic rearrangements, comprises up to $75 \%$ of the chromosome anomalies in HPE. It has also been reported that about approximately $20 \%$ of the anomalies had were triploidy and $1 \%-2 \%$ had trisomy $18(21,22)$. In our cohort, the detection frequencies of trisomy 13 , trisomy 18 , and triploidy were 59.4, 12.5 and $7.8 \%$, respectively, with much lower rates for trisomy 13 and triploidy but a higher frequency of trisomy 18 than previously reported. This finding might be a coincidence, because targeted sequencing of HPE-related genes was not performed and the aberration is probably confined to extra-foetal tissues. De novo or familial $7 \mathrm{q}$ deletions were also observed at significant rates (7.8\%-7.8\% respectively) in our cohort, probably due to the targeted FISH analysis for 7q microdeletions. In our cohort, we detected two incidental chromosome abnormalities, one, of them with a paternally transmitted inv (11), and the other with trisomy 20 . The inv(11) is probably not related to HPE in the foetus since it was also present in the healthy father as well, the region does not involve a known
HPE gene (1-3). The significance of trisomy 20 in extra embryonic cells is unclear, and to the best of our knowledge, no cases of HPE with prenatal diagnosis of trisomy 20 have been reported.

Structural chromosomal anomalies associated with HPE have also been reported. In HPE, structural chromosome anomalies are mostly seen in 13q, 18p11.2, 7q36, 3p24, p21 and $21 \mathrm{q} 22.3$ regions. These regions are also the loci where autosomal dominant inherited HPE genes are localized (23). Structural chromosome anomalies have resulted in the identification of novel genes associated with HPE. In this cohort, the four identified unbalanced products of maternal reciprocal translocations had one breakpoint at 3p23, 3q28, 15q26.2, 21q22.3, and shared a terminal breakpoint at $7 q 36$. In all these cases, the HPE phenotype is presumably related to monosomy of 7q36>qter, which encompasses the SHH locus. However, in one, the derivative chromosome had a concomitant duplication of 3p23->pter, which may have contributed to the phenotype, as the association between $3 p$ duplication and HPE is well documented (24). Ginocchio et al. reviewed HPE cases with $3 p$ duplications and almost all had alobar HPE (24). Our case also displayed alobar HPE. Another unbalanced offspring of a balanced reciprocal translocation was monosomic for 7q36->qter and trisomic for 21q22.3->qter. The minimal critical region of HPE1 locus is on $21 q 22.3$ the the monosomy of this region is associated with HPE; however, HPE has rarely been reported in association with trisomy 21 (25). Only one case with partial duplication of 21q22.3 and monosomy 18p11.2 as an unbalanced product of a maternal translocation has been reported to display HPE, which can be attributed to the monosomy 18p, which includes TGIF1 gene (26). Another familial case reported by Balci et al. showed a clear association between HPE and with monosomy 18p (27). A de novo terminal deletion of $18 p$ was identified in our cohort by multiplex ligation-dependent probe amplification, and confirmed by subtelomeric FISH studies, and HPE was associated with haploinsufficiency of the TGIF1 gene located at 18p11.

Bendavid et al. demonstrated that submicroscopic aberrations are a most frequent causes of HPE, with $17 \%$ of de novo anomalies detected by aCGH analysis (28). Performing aCGH in 29 cases with normal karyotype revealed one chromosome anomaly that should have been detected by karyotyping, but was missed due to poor quality chromosome preparations. All other CNVs identified were in known recurrent regions.

To date, more than 14 genes have been associated with non-syndromic HPE. SHH (HPE3) located on 7q36 was described first, and is the most frequent causative gene in nonchromosomal and nonsyndromic HPE, accounting for approximately $12 \%$ of cases (18). According 
to Raam et al. in all non-syndromic HPE patients with normal chromosomes, molecular analysis should be performed for the most common genes SHH, ZIC2, and SIX3 as a first step (29). If no mutation is found, then TGIF1 and GLI family zinc finger 2 should be analysed. Mutations in the four major genes (SHH, ZIC2, SIX3, TGIF1) were identified in $25 \%$ of cases. The SHH, SIX3, and TGIF1 mutations were inherited in more than $70 \%$ of these cases, whereas $70 \%$ of ZIC2 mutations occurred de novo. There was a positive correlation between the severity of the brain malformation and facial features for SHH, SIX3 and TGIF1 mutations, but no such correlation was shown for ZIC2. The most severe HPE types were associated with SIX3 and ZIC2 mutations, whereas microforms were associated with $\mathrm{SHH}$ mutations (30). HPE was found in five families in our cohort in at least two pregnancies, and only one of these families was consanguineous (the parents were first cousins). In one case with normal karyotype, a physical examination of the parents revealed that the mother had a single maxillary central incisor, and in the consanguineous family, both parents had hypotelorism. Molecular studies were performed on the two families with normal karyotypes and causative genes were SHH in one family (Solomon' personel communication) and SIX3 in the other (Duborg' personel communication).

Families are understandably concerned about the recurrence risk of HPE; therefore, the delineation of HPE etiology is very important for genetic counselling and the monitoring of future pregnancies. If a genetic aetiology is found, prenatal diagnosis should be recommended in the first trimester of subsequent pregnancies. However, the wide spectrum of the phenotypic variation should be taken into consideration, and USG examination is crucial.

\section{CONCLUSION}

When HPE is diagnosed prenatally, physical examination and cytogenetic analysis of the parents is essential. If high-resolution chromosome analysis is performed, almost all aberrations, including specific microdeletions, can be detected in more than half of the patients. As the identification of submicroscopic aberrations aids in the identification of new loci and genes, aCGH should be performed as a secondary test in cases with normal karyotype. If aCGH studies also reveal normal results, sequencing of related genes should be the third test performed. However, incomplete penetrance and variable phenotypic presentation should be taken into consideration during genetic counselling.

We are planning to investigate single gene disorders in cases where chromosome anomalies are not detected by any available technique in this study.
Note: The editor in chief was not involved in the evaluation, peer-review and decision processes of the article, and these processes were carried out by the associate editors.

Acknowledgment: The authors wish to special thanks to Prof. Dr. Albert Schinzel for his critical review of the manuscript. We are grateful to the family members for their participation in this study.

Ethics Committee Approval: This study was approved by the Ethical Committee of the Istanbul University, Istanbul Faculty of Medicine (Date:27.07.2011, No:2011/1275-642).

Informed Consent: Written consent was obtained from the participants.

Peer Review: Externally peer-reviewed.

Author Contributions: Conception/Design of Study- B.K., S.E., H.K., A.Y., N.B.S., I.H.K., R.H. S.B.; Data Acquisition- B.K., S.E., H.K., A.Y., N.B.S., i.H.K., R.H. S.B.; Data Analysis/InterpretationB.K., S.E., H.K., A.Y., N.B.S., I.H.K., R.H. S.B.; Drafting Manuscript- B.K., S.E., H.K., A.Y., N.B.S., I.H.K., R.H. S.B.; Critical Revision of Manuscript- B.K., S.E., H.K., A.Y., N.B.S., I.H.K., R.H. S.B.; Final Approval and Accountability- B.K., S.E., H.K., A.Y., N.B.S., i.H.K., R.H. S.B.

Conflict of Interest: Authors declared no conflict of interest.

Financial Disclosure: This work was supported by the Research Fund of Istanbul University (Project No:6155, 17468 and 615722730)

Not: Makalenin değerlendirme, hakem ve karar süreçlerinde baş editör yer almamış, ilgili yardımcı editörler tarafından süreçler yürütülmüştür.

Teşekkür: Yazarlar, makalede eleştirel değerlendirmesi için Prof. Dr. Albert Schinzel'e ve aile üyelerine çalışmaya katılmaları nedeniyel teşekkür ediyorlar.

Etik Komite Onayı: Bu çalışma için etik komite onayı İstanbul Üniversitesi, İstanbul Tıp Fakültesi Etik Kurulu'ndan alınmıştır (Tarih:27.07.2011, Sayı:2011/1275-642).

Bilgilendirilmiş Onam: Katılımcılardan bilgilendirilmiş onam alınmıştır.

Hakem Değerlendirmesi: Dış bağımsız.

Yazar Katkıları: Çalışma Konsepti/Tasarım- B.K., S.E., H.K., A.Y., N.B.S., I.H.K., R.H. S.B.; Veri Toplama- B.K., S.E., H.K., A.Y., N.B.S., i.H.K., R.H. S.B.; Veri Analizi/Yorumlama- B.K., S.E., H.K., A.Y., N.B.S., I.H.K., R.H. S.B.; Yazı Taslağı- B.K., S.E., H.K., A.Y., N.B.S., I.H.K., R.H. S.B.; Iç̧eriğin Eleştirel İncelemesi- B.K., S.E., H.K., A.Y., N.B.S., I.H.K., R.H. S.B.; Son Onay ve Sorumluluk B.K., S.E., H.K., A.Y., N.B.S., I.H.K., R.H. S.B

Çıkar Çatışması: Yazarlar çıkar çatışması beyan etmemişlerdir.

Finansal Destek: Bu çalışma İstanbul Üniversitesi Araştırma Projeleri Başkanlığı tarafından desteklenmiştir (Proje No: 6155, 17468 ve 615722730). 


\section{REFERENCES}

1. Solomon BD, Lacbawan F, Mercier S, et al. Mutations in ZIC2 in human holoprosencephaly: description of a novel ZIC2 specific phenotype and comprehensive analysis of 157 individuals. J Med Genet 2010;47(8):513-24. [CrossRef]

2. Cohen HL \& Sivit CJ. Holoprosencephaly. In: Cohen HL. Sivit CJ. (eds.) Fetal and pediatric ultrasound: a casebook approach. New York: McGraw-Hill. 2001.

3. Muenke M, Beachy PA. Genetics of ventral forebrain development and holoprosencephaly. Curr Opin Genet Dev 2000;10(3):262-9. [CrossRef]

4. Barkovich A, Quint DJ. Middle interhemispheric fusion: an unusual variant of holoprosencephaly. AJNR Am J Neuroradiol 1993;14(2):431-40.

5. Hahn JS, Barnes PD, Clegg NJ. Septopreoptic holoprosencephaly: a mild subtype associated with midline craniofacial anomalies. AJNR Am J Neuroradiol 2010;31(9):1596-601. [CrossRef]

6. Belloni E, Muenke M, Roessler E, et. al. Identification of Sonic hedgehog as a candidate gene responsible for holoprosencephaly. Nat Genet 1996;14(3):353-6. [CrossRef]

7. Roessler E, Belloni E, Gaudenz K, et al. Mutations in the human Sonic Hedgehog gene cause holoprosencephaly. Nat Genet 1996;14(3):357-60. [CrossRef]

8. Rosenfeld JA, Ballif BC, Martin DM, et al. Clinical characterization of individuals with deletions of genes in holoprosencephaly pathways by aCGH refines the phenotypic spectrum of HPE. Hum Genet 2010;127(4):42140. [CrossRef]

9. Brown SA, Warburton D, Brown LY, et al. Holoprosencephaly due to mutations in ZIC2, a homologue of Drosophila oddpaired. Nat Genet 1998;20(2):180-3. [CrossRef]

10. Wallis DE, Roessler $E$, Hehr $U$, et al. Mutations in the homeodomain of the human SIX3 gene cause holoprosencephaly. Nat Genet 1999;22(2):196-8. [CrossRef]

11. Gripp KW, Wotton D, Edwards MC, et al. Mutations in TGIF cause holoprosencephaly and link NODAL signalling to human neural axis determination. Nat Genet 2000;25(2):2058. [CrossRef]

12. Ming JE, Kaupas ME, Roessler $E$, et al. Mutations in PATCHED-1, the receptor for SONIC HEDGEHOG, are associated with holoprosencephaly. Hum Genet 2002;110(4):297-301. [CrossRef]

13. Pineda-Alvarez DE, Dubourg $C$, et al. Current recommendations for the molecular evaluation of newly diagnosed holoprosencephaly patients. Am J Med Genet C Semin Med Genet 2010;154C(1):93-101. [CrossRef]

14. Dubourg C, Lazaro L, Pasquier $L$, et al. Molecular screening of $\mathrm{SHH}, \mathrm{ZIC2}, \mathrm{SIX} 3$, and TGIF genes in patients with features of holoprosencephaly spectrum: Mutation review and genotype-phenotype correlations. Hum Mutat 2004;24(1):43-51. [CrossRef]

15. Lewis AJ, Simon EM, Barkovich AJ, et al. Middle interhemispheric variant of holoprosencephaly: a distinct cliniconeuroradiologic subtype. Neurology 2002;24;59(12):1860-5. [CrossRef]
16. Cohen MM, Jr. 1989. Perspectives on holoprosencephaly: Part I. Epidemiology, genetics, and syndromology. Teratology 1989;40(3):211-35. [CrossRef]

17. Ming JE, Muenke M. Holoprosencephaly: from Homer to Hedgehog. Clin Genet 1998;53(3):155-63. [CrossRef]

18. Solomon BD, Bear KA, Wyllie A, et al. Genotypic and phenotypic analysis of 396 individuals with mutations in Sonic Hedgehog. J Med Genet 2012;49(7):473-9. [CrossRef]

19. Wraith JE, Super M, Watson GH, Phillips M. Velo-cardiofacial syndrome presenting as holoprosencephaly. Clin Genet 1985;27(4):408-10. [CrossRef]

20. Heijmans BT \& Mill J. Commentary: The seven plagues of epigenetic epidemiology. Int J Epidemiol 2012;41(1):74-87. [CrossRef]

21. Bullen PJ, Rankın JM, Robson SC. Investigation of the epidemiology and prenatal diagnosis of holoprosencephaly in the North of England. Am J Obstet Gynecol 2001;184(6):1256-62. [CrossRef]

22. Goetzinger KR, Stamilio DM, Dicke JM, et al. Evaluating the incidence and likelihood ratios for chromosomal abnormalities in fetuses with common central nervous system malformations. Am J Obstet Gynecol 2008;199(3):285.e1-6. [CrossRef]

23. Schell $U$, Wienberg J, Kohler A, et al. Molecular characterization of breakpoints in patients with holoprosencephaly and definition of the HPE2 critical region 2p21. Hum Mol Genet 1996;5(2):223-9. [CrossRef]

24. Ginocchio VM, De Brasi D, Genesio R, et al. Sonic Hedgehog deletion and distal trisomy $3 p$ in a patient with microphthalmia and microcephaly, lacking cerebral anomalies typical of holoprosencephaly. Eur J Med Genet 2008;51(6):658-65. [CrossRef]

25. Basu S, Kumar A, Das BK. Down syndrome (trisomy 21) with premaxillary agenesis and semilobar holoprosencephaly. Am J Med Genet A 2009;149A(11):2578-80. [CrossRef]

26. Chen $\mathrm{CP}$, Chern $\mathrm{SR}$, Wang $\mathrm{W}$, et al. Prenatal diagnosis of partial monosomy $18 p(18 p 11.2-->p t e r)$ and trisomy 21 q(21q22.3-->qter) with alobar holoprosencephaly and premaxillary agenesis. Prenat Diagn 2001;21(5):346-50. [CrossRef]

27. Balcı S, Tumer C, Karaca C, Bartsch O. Familial ring (18) mosaicism in a 23-year-old young adult with $46, X Y, r(18)$ (::p11-->q21::)/46,XY karyotype, intellectual disability, motor retardation and single maxillary incisor and in his phenotypically normal mother, karyotype 47,XX, +r(18)(::p11->q21::)/46,XX. Am J Med Genet A 2011;155A(5):1129-35. [CrossRef]

28. Bendavid C, Rochard L, Dubourg C, et al. Array-CGH analysis indicates a high prevalence of genomic rearrangements in holoprosencephaly: an updated map of candidate loci. Hum Mutat 2009;30(8):1175-82. [CrossRef]

29. Raam MS, Solomon BD, Muenke M. Holoprosencephaly: a guide to diagnosis and clinical management. Indian Pediatr 2011;48(6):457-66. [CrossRef]

30. Mercier S, Dubourg C, Garcelon N, et al. New findings for phenotype-genotype correlations in a large European series of holoprosencephaly cases. J Med Genet 2011;48(11):75260. [CrossRef] 